\title{
19
}

\section{SOCIAL SUSTAINABILITY IN SOCIAL AND AFFORDABLE HOUSING}

\author{
Meryn Severson and Esther de Vos
}

\section{Introduction}

Sustainability is generally understood as meeting the needs of current generations without compromising the ability of future generations to meet their own needs (Brundtland, 1987), or, as Dujon and colleagues (2013) write, sustainability is simply "a fulfilling present and a renewable and regenerative future" (p. 2). Within this understanding of sustainability, the three dimensions or pillars - environmental, economic and social - have been well established in research and theory (Colantonio \& Dixon, 2011; Dillard et al., 2009). However, in spite of the recognition of all three dimensions, there has been less emphasis on developing the social dimension, with no agreed-upon definition or form of measurement (Shirazi \& Keivani, 2019).

At the same time, there is growing recognition that the current model for social and affordable housing ${ }^{1}$ in Canada is unsustainable. However, this dialogue tends to focus more so on the financial or environmental dimensions. While these dimensions are important, we argue that conceptualizing social sustainability in the context of social and affordable housing is no less important, and that in order to operationalize social sustainability in the sector, it must also be measurable. With federal, provincial and municipal governments all increasingly recognizing the value of social sustainability (Government of Alberta, 2017; Government of Canada, 2017; City of Edmonton, 2010), the development of Capital Region Housing's measurement framework is timely and will contribute to the literature on evaluating social sustainability.

Capital Region Housing is one of the largest social and affordable housing providers in Canada, managing over 4,500 social housing units, 700 affordable (near market units) and 130 mixedincome units. Capital Region Housing is actively working to improve the sustainability of the affordable housing sector and support the well-being of tenants. Sustainability is a guiding principle at Capital Region Housing, and, consequently, Capital Region Housing has invested in developing an understanding of social sustainability that is specific to the context of social and affordable housing.

We have taken steps to conceptualize social sustainability for a social and affordable housing provider in Edmonton, Alberta (de Vos \& Severson, 2018). This conceptualization takes into account the literature on social sustainability and includes sustainable community considerations as well as individual and community resilience. This chapter builds on the previous work designed to develop an understanding of social sustainability in the context of social and affordable housing in Canada to measuring social sustainability in this context. In this chapter, we will first 
provide a brief overview of this conceptualization before turning to a review of other social sustainability frameworks and their measures. We then outline the measurement framework we have developed based on the best practices from the literature and our conceptualization of social sustainability drawn from the literature and our context as a social and affordable housing provider.

\section{Conceptualizing Social Sustainability in Social and Affordable Housing}

There has been an increased focus over the last number of years on social sustainability, predominantly from urban researchers, but also from the work of municipal governments, such as the City of Vancouver and the City of Edmonton amongst Canadian municipalities. However, current conceptualizations are often pragmatic and limited by available data (Littig \& Griessler, 2005; Boström, 2012). Thus, some argue that social sustainability is best understood as a framework rather than a definition, which must be developed and clarified to be used as a tool to communicate, make decisions and measure development (Boström, 2012).

The literature predominantly recognizes two models of sustainability: the concentric model which predicates the social and financial dimensions on the environmental dimension, and the Venn diagram model where all dimensions are equal to each other (McKenzie, 2004; Manzi et al., 2010). These two models have informed the way in which social sustainability has been approached. We have adopted the anthropocentric approach, which draws from the Venn diagram model and emphasizes human relationships and livability (Littig \& Griessler, 2005; Colantonio, 2009; Vallance et al., 2011; Manzi et al., 2010). Based on the literature on sustainable cities and communities as well as individual and community resilience, we believe that both aspects are important when conceptualizing social sustainability in the context of social and affordable housing.

In developing our conceptualization of social sustainability for social and affordable housing, we recognize that housing plays multiple roles in our lives, including both as a physical built environment and as a home where people live with associated pyschosocial impacts. This conceptualization draws from Ancell and Thompson-Fawcett's (2008) model of the social sustainability of mediumdensity housing which recognizes the multiple roles played by housing. We also draw from the City of Vancouver's (2005) definition of social sustainability which includes basic needs (labelled primary needs in Ancell and Thompson-Fawcett's model) and individual and community capacity building (labelled higher-order needs or ultimate needs in Ancell and Thompson-Fawcett's model) that contribute to improved quality of life in both the built environment and human environment.

We understand social sustainability as meeting both primary and basic needs, such as access to affordable nutritious food and safe and affordable housing, and higher-order needs, such as capacity and well-being, to improve quality of life for current generations without compromising the ability of future generations to meet these needs. For an affordable housing provider, the key methods to improve quality of life is through the housing we provide, but we also recognize that housing provides opportunities to meet non-housing needs and higher-order needs. This conceptualization not only recognizes that social sustainability is ultimately grounded in improving quality of life and liveability but also housing's unique role in meeting basic needs and facilitating higher-order needs, and specifically focuses on both housing and tenants.

We also recognize four principles that must guide the actions taken to meet these basic and higher-order needs. These four principles are:

1. equity - understanding that some individuals and groups require differing levels of support in order to flourish;

2. inclusion - both the right and the opportunity to participate in and enjoy all aspects of community life; 
3. resiliency - the ability to adapt to change; and

4. security - both economic and physical security and stability.

Further, the actions we take to meet these needs must align with intergenerational equity (reducing inequality for this generation) and intragenerational equity (ensuring that the actions taken today do not negatively impact future generations and instead act to improve equity in the future). Building from this conceptualization of social sustainability, we have worked to develop a measurement framework based on the literature, which we outline next.

\section{Measuring Social Sustainability: A Review of the Literature}

While there is no agreed-upon conceptualization and measurement framework for social sustainability, there are a number of frameworks that have been developed for both social sustainability and other similar concepts such as social value that are geared towards the measurement of social outcomes and impacts. For example, social value has a well-developed measurement framework and is generally understood as the benefits created by social programs and activities (such as affordable housing) and experienced by people and communities that are not captured by the market, and as such it is easier to miss (CIH UK, 2015). It includes consideration for the well-being of individuals and communities as well as of the environment. It is often measured through the social return on investment (SROI) ratio, which is the social, economic and environmental value of an activity's impact relative to the investments and costs to operate the activity (CIH UK, 2015). Social impact assessments, on the other hand, try to assess the possible social, cultural and economic impacts of a proposed project or change on individuals or communities (Colantonio, 2009; Vanclay, 2003). While these frameworks have been increasingly adopted and share some similarities with sustainability, their applicability to social sustainability remains contested (Colantonio, 2009). Particularly, these measures miss the focus on current and future generations that is key to a sustainability approach (Dujon, Dillard \& Brennan, 2013). Further, in contrast to social value/SROI or social impact assessments frameworks, a single summarized measure for social sustainability is not possible due to the multidimensional nature of social sustainability that includes both tangible and intangible factors (Colantonio et al., 2009; Colantonio \& Dixon, 2011; Bacon, Cochrane \& Woodcroft, 2012).

Instead, most social sustainability measurement frameworks do not try to establish a single aggregated outcome, instead tending towards data visualization methods that allow the different dimensions of social sustainability to be compared without being aggregated (Colantonio et al., 2009; Bacon, Cochrane \& Woodcroft, 2012). These frameworks are also often focused on a specific scale, as social sustainability is considered to be multi-scalar but most practically applied and experienced at the neighbourhood or community scale (Magis, 2010; Shirazi \& Keivani, 2019). Combined with the focus on urban places and cities within the social sustainability field, much of the work on measuring social sustainability to date has focused on policy development at the regional and municipal level, developing frameworks that can guide political decisionmaking and policy development (Davidson, 2012). As a result, these frameworks often focus more on the assessment of policy than on tangible social conditions (Colantonio, 2009; Murphy, 2012) and function more as guidelines for decision-making than as formal assessment tools. These policy frameworks are useful in conceptualizing the larger system in which actions to improve social sustainability are situated and accounting for factors such as cultural change and the need to actively design policies that benefit the poorest and most marginalized citizens (Polèse \& Stren, 2000). 
Further, with the increasing role of municipalities in supporting social development and responding to social issues, it is often their responsibility to create conditions for reducing exclusion and to develop "bridges" to link disparate parts of the community together, another key aspect of social sustainability (Stren \& Polèse, 2000; Davidson, 2010; Magis, 2010; Polèse \& Stren, 2000; Colantonio \& Dixon, 2011; Dempsey et al., 2011). As such, measures for social sustainability adopted by municipalities are often measured at a collective level. For the City of Edmonton, reflective of their approach to social sustainability at a policy and program role, the City has developed a corporate measure for sustainability as a whole, measured as the percentage of Edmontonians who live in "complete communities". Similarly, the City of Vancouver's indicators for social sustainability are drawn from the Federation of Canadian Municipalities Quality of Life Indicators (City of Vancouver, 2006), again recognizing the role of municipalities in social sustainability and improving quality of life.

Within these policy frameworks for social sustainability, housing is a recurring theme, recognizing that factors like spatial segregation, affordability, zoning practices, and the physical quality of housing can have major impacts on individual and community well-being (Polèse \& Stren, 2000; Polèse, 2000; Colantonio et al., 2009; Carlson \& Everett, 2013). However, there are few frameworks for analyzing social sustainability in the context of housing presently available. Those that do exist (Dixon \& Woodcraft, November 2013; Bacon, Cochrane, \& Woodcraft, 2012; Ancell \& Thompson-Fawcett, 2008; and to some extent Pullen et al., 2010) tend to select measurement indicators situated at higher levels of needs, such as the dimensions "Social and cultural life" and "Voice and influence" in Dixon and Woodcraft's framework or relationships in the community and neighbourhood quality in Ancell \& Thompson-Fawcett's framework (2008).

Looking at these frameworks in more detail highlights that these frameworks are still mostly focused on housing in the context of neighbourhoods. For example, In the UK, where national planning priorities have incentivized housing developers to consider the social implications of their development strategies, the Berkeley Group commissioned researchers (Bacon, Cochrane \& Woodcroft, 2012; Dixon \& Woodcroft, 2013) to develop a social sustainability framework for their role as private housing developer. Their conceptualization of social sustainability is strongly rooted in the neighbourhood and built environment, reflective of their role as a developer and builder (Bacon, Cochrane \& Woodcraft, 2012). Their measurement framework consists of three dimensions of social sustainability - "infrastructure and social amenities", "voice and influence" and "social and cultural life" - which are measured using 13 different indicators drawn from a survey conducted in each neighbourhood, as well as publicly accessible data from national surveys. These indicators predominantly focus on the neighbourhood, such as "accessible street layout" and "physical space on development that is adaptable in the future". Although social equity, justice, access to education and employment are common themes in social sustainability frameworks more generally, the authors chose to exclude them from the housing framework, arguing that they fall beyond the scope of a housing developer (Dixon \& Woodcraft, 2013). The dimensions and indicators in their measurement framework are summarized in Table 19.1.

While Bacon and colleague's framework for the Berkeley Group focuses on the role of the private developer and measuring and supporting social sustainability in new and revitalized neighbourhoods, Shirazi and Keivani's (2019) framework focuses on measuring social sustainability in urban neighbourhoods more broadly. Similar to Bacon and colleagues, Shirazi and Keivani include three dimensions of social sustainability, which they call the "triad of social sustainability in urban neighbourhoods" and which all include the concept of "neighbour" in different ways. "Neighbouring" focuses on soft infrastructure or non-physical 
TABLE 19.1 Summary of Key Social Sustainability Measurement Frameworks Reviewed

\begin{tabular}{|c|c|c|c|}
\hline Source & Focus & Dimensions & Indicators \\
\hline \multirow[t]{3}{*}{$\begin{array}{l}\text { Bacon, } \\
\text { Cochrane \& } \\
\text { Woodcraft } \\
(2012)\end{array}$} & \multirow[t]{3}{*}{$\begin{array}{l}\text { New and } \\
\text { revitalized } \\
\text { neighbourhoods }\end{array}$} & $\begin{array}{l}\text { Amenities and } \\
\text { infrastructure }\end{array}$ & $\begin{array}{l}\text { Provision of community space } \\
\text { Transport links } \\
\text { Place with distinctive character } \\
\text { Integration with wider } \\
\text { neighbourhood } \\
\text { Accessible street layout } \\
\text { Physical space on development } \\
\text { that is adaptable in future } \\
\text { Positive local identity }\end{array}$ \\
\hline & & Social and cultural life & $\begin{array}{l}\text { Relationships with neighbours } \\
\text { Well-being } \\
\text { Feelings of safety }\end{array}$ \\
\hline & & Voice and influence & $\begin{array}{l}\text { Perceptions of ability to influence } \\
\text { local area } \\
\text { Willingness to act to improve area }\end{array}$ \\
\hline \multirow{3}{*}{$\begin{array}{l}\text { Shirazi \& } \\
\text { Keivani } \\
(2018)\end{array}$} & \multirow[t]{3}{*}{$\begin{array}{l}\text { Urban } \\
\text { neighbourhoods }\end{array}$} & $\begin{array}{l}\text { Neighbour (population } \\
\text { profile) }\end{array}$ & Social mix \\
\hline & & $\begin{array}{l}\text { Neighbouring (soft } \\
\text { infrastructure) }\end{array}$ & $\begin{array}{l}\text { Social networking and interaction } \\
\text { Safety and security } \\
\text { Sense of attachment } \\
\text { Participation } \\
\text { Quality of neighbourhood } \\
\text { Quality of home }\end{array}$ \\
\hline & & $\begin{array}{l}\text { Neighbourhood (hard } \\
\text { infrastructure) }\end{array}$ & $\begin{array}{l}\text { Density } \\
\text { Mixed land use } \\
\text { Urban pattern and connectivity } \\
\text { Building typology } \\
\text { Quality of centre } \\
\text { Access to facilities }\end{array}$ \\
\hline \multirow{3}{*}{$\begin{array}{l}\text { Ancell \& } \\
\text { Thompson- } \\
\text { Fawcett } \\
(2008)\end{array}$} & \multirow[t]{3}{*}{$\begin{array}{l}\text { Medium-density } \\
\text { housing }\end{array}$} & Fundamental needs & $\begin{array}{l}\text { Affordability } \\
\text { Housing quality }\end{array}$ \\
\hline & & Intermediate needs & $\begin{array}{l}\text { Transport } \\
\text { Facilities }\end{array}$ \\
\hline & & Ultimate needs & $\begin{array}{l}\text { Neighbourhood quality } \\
\text { Relationships in the community }\end{array}$ \\
\hline
\end{tabular}

Source: Summarized from Bacon, Cochrane \& Woodcraft (2012); Shirazi \& Keivani (2018); and Ancell \& ThompsonFawcett (2008).

factors, "neighbourhood" focuses on hard infrastructure or physical factors and "neighbour" highlights the population profile or social mix of the neighbourhood. From this conceptualization, they selected 13 indicators from the literature that are associated with social sustainability and well-being, such as sense of attachment, participation, density, mixed land use and social mix of the population. Shirazi and Keivani's (2019) framework is unique in that it is an operational, integrative framework that moves from conceptualization all the way to measurement. It is also unique in that it is broad enough to be used across all neighbourhoods, without reflecting a specific role within that neighbourhood. The indicators in this framework are summarized in Table 19.1.

While higher-order needs are thoroughly explored in almost all social sustainability frameworks reviewed (see Bramley et al., 2009; Chiu, 2003), basic needs seem to be implicitly 
assumed as a foundation for community well-being but are not specifically addressed (Magis \& Shinn, 2009), except for the City of Vancouver (2005) and Ancell and Thompson-Fawcett's model (2008). Their model of social sustainability in medium-density housing (2008) explicitly recognizes needs, based on Maslow's hierarchy of need. In this model, they emphasize that basic needs must be met before higher-order needs can be the focus of social sustainability work. They include affordability and quality as fundamental needs in their conceptual evaluation model, but do not include non-shelter basic needs. However, their model is still unique in that it explicitly recognizes primary or basic needs as well as higher-order needs and focuses on housing, specifically medium-density housing. This model is also summarized in Table 19.1.

There are some key caveats that recur throughout the literature on measuring social sustainability that should be considered when designing and interpreting frameworks for social sustainability. Colantonio and colleagues (2009) contend that social sustainability is better understood as a socio-historical process than as an end state; the target for social sustainability is constantly moving, and a final state of "ultimate" social sustainability will never be achieved. This differs from environmental sustainability which might be oriented towards a hard target (such as carbon neutrality), which could eventually be attained. Conversely, McKenzie suggests that social sustainability is often described as a "condition" which can exist at a given point in time (2004), but more recent work has tended in the direction of a process-oriented view of social sustainability. This temporality has been reflected in many definitions of social sustainability, which identify the well-being of future generations as present goals that must be planned and accounted for.

While some consensus is beginning to emerge in measuring social sustainability, particularly in policy frameworks and frameworks at the neighbourhood scale, frameworks for measuring social sustainability in the context of social and affordable housing providers remain limited. In general, the literature seems to agree on the importance of developing frameworks based around indicators that:

- are community-oriented rather than individually oriented,

- can be benchmarked to standardized data sources such as censuses and other national surveys,

- $\quad$ are concerned with a range of aspects of social sustainability and

- can be compared across time to evaluate progress in promoting social sustainability and guide actions to support social sustainability.

Drawing from this review of social sustainability frameworks and from our conceptualization drawn from the social sustainability literature and housing literature, we now turn to our measurement framework developed for the context of social and affordable housing.

\section{Creating a Measurement Framework for Social and Affordable Housing}

Based on our conceptual model for social sustainability, we have developed the following measurement framework illustrated in Figure 19.1. We identify four key dimensions for social sustainability within the context of social and affordable housing:

1. housing standards,

2. non-housing needs,

3. community integration and social inclusion and

4. capacity building and resiliency. 


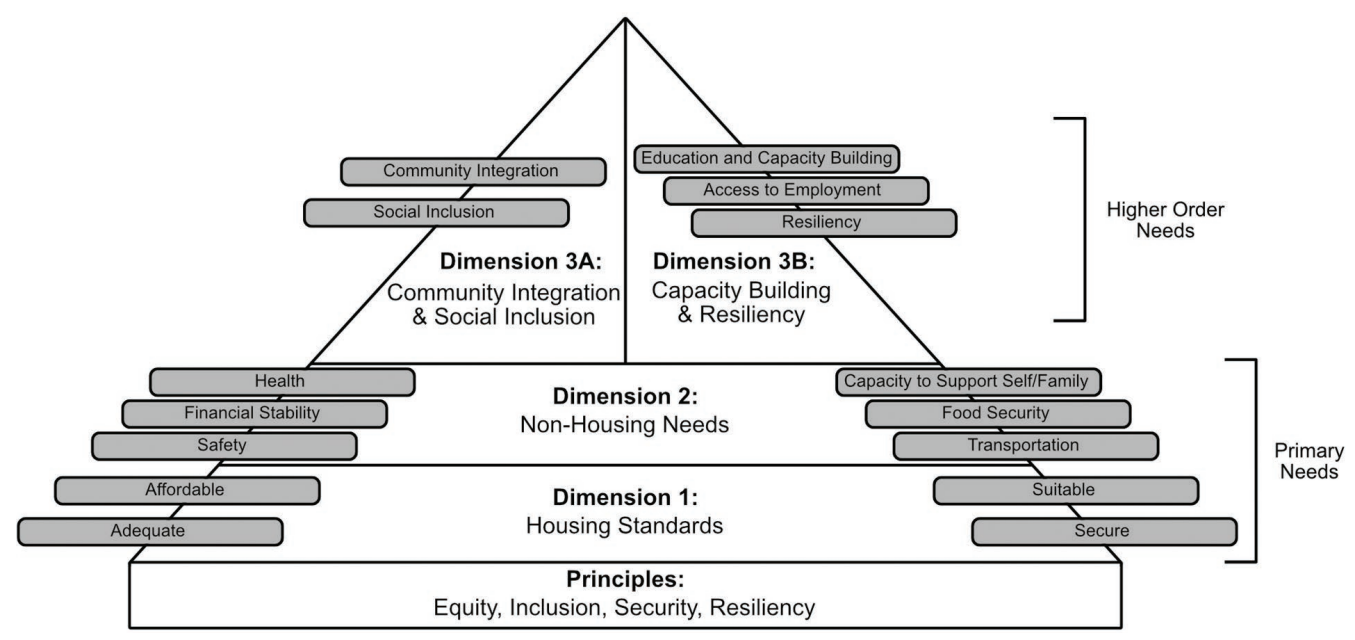

FIGURE 19.1 Conceptual Model for Measuring Social Sustainability in Social and Affordable Housing.

Source: Capital Region Housing.

Each of these dimensions has a series of indicators drawn from the literature which can be measured both quantitatively and qualitatively. Recognizing that all areas of the framework are necessary to support social sustainability, none of the indicators are weighted. However, a larger number of indicators are included for the basic needs-levels of the framework, both because these areas have more tangible and measurable factors and recognizing the importance of satisfying basic needs before higher-order needs can be addressed (City of Vancouver, 2005; Ancell \& Thompson-Fawcett, 2008; Magis \& Shinn, 2009).

Like the other measurement frameworks reviewed, this framework includes a mix of survey collected measures, administrative data and external measures. Most of these measures are collected through Capital Region Housing's biennial Tenant Wellbeing Survey which is based on best practices in the well-being literature and uses standardized questions from Statistics Canada as much as possible (see Capital Region Housing, 2018). External measures such as neighbourhood crime statistics and the CMHC/Statistics Canada's social inclusion and proximity measures (CMHC, 2020; Statistics Canada, 2020) are also included. In total, our measurement framework for social sustainability includes 49 different measures for 15 different indicators along the four different dimensions. Each of these dimensions and their indicators and measures will be outlined below.

\section{Dimension 1: Housing Standards}

Housing retains a unique place within the framework of social sustainability as it is both a basic need and fundamental to survival, but also contributes psychosocial benefits (Carter \& Polevychok, 2004; CMHC, 2004; Dunn et al., 2006). However, these benefits of housing are conditional on housing being affordable, adequate, suitable and secure. If these conditions are not met, housing cannot contribute to higher-order needs (Ancell \& Thompson-Fawcett, 2008). Thus, our framework recognizes that the first set of needs we must work to meet are centred on providing housing and ensuring it is affordable, adequate, secure and suitable.

This necessarily determines our indicators for this dimension of social sustainability. These indicators are already defined by Statistics Canada and CMHC (Statistics Canada 2017). Housing 
TABLE 19.2 Indicators and Measures for Dimension 1: Housing Standards

\begin{tabular}{llll}
\hline Indicator & Measure & Data Source & Target \\
\hline Affordable & $\begin{array}{l}\text { Number of new units under construction } \\
\text { Percentage of portfolio in mixed-income developments } \\
\text { Percentage of priority (wait) list allocated housing }\end{array}$ & $\begin{array}{l}\text { Administrative data } \\
\text { Administrative data }\end{array}$ & $\begin{array}{l}\text { Increase } \\
\text { Increase }\end{array}$ \\
& $\begin{array}{l}\text { Difference between household net income and } \\
\text { annual living wage amount }\end{array}$ & Administrative data & Decrease \\
Adequate & Years since construction or last renovation & Administrative data & Decrease \\
& Facility condition index & Administrative data & Decrease \\
Suitable & Accessibility & Administrative data & Increase \\
& Number of people per bedroom & Administrative data & Decrease \\
Secure & Number of months in housing & Administrative data & Increase \\
& Feeling of safety in home & Well-being survey & Increase \\
& Number of evictions & Administrative data & Decrease \\
& Vacancy rate & Administrative data & Decrease \\
\hline
\end{tabular}

Source: Capital Region Housing.

is considered affordable when it costs $30 \%$ or less of a household's before-tax income. Adequacy is defined as housing that does not need major repairs, and suitability is defined as housing with enough bedrooms for the household based on the National Occupancy Standards (Statistics Canada, 2017). Security is also considered a component of the right to housing (CESCR, 1991), and so we have included it as an indicator of these housing standards.

However, while indicators are necessarily determined for this dimension, the measures are not. Statistics Canada and the CMHC measure these housing standards as the percentage of the population who report falling below one or more of these housing standards (except for security). This does not make sense though for a housing provider whose mandate is to provide safe, secure and affordable housing and who uses these standards in our operations. This includes using the suitability standard when allocating housing to new tenants and using the affordability standard to set monthly rent amounts. Rather than assessing the households who live in our housing as measured by Statistics Canada, we want to assess the housing we are providing and ensure that we are providing housing that meets these standards. These measures are outlined in Table 19.2.

\section{Dimension 2: Non-Housing Needs}

As an affordable housing provider that is specifically concerned with support for pathways out of poverty, Capital Region Housing has adopted a more holistic model of social sustainability, with indicators that fall outside the mandate of a typical landlord or housing developer (see Dixon \& Woodcraft, 2013, for an alternate perspective). Tenants have other, non-housing needs, especially food security (Kirkpatrick \& Tarasuk, 2007). Living in affordable, safe and secure housing provides an opportunity to facilitate meeting other non-housing basic needs (Dunn et al., 2006; CMHC, 2004), which, in turn, support social sustainability. Thus, the second set of primary needs focuses on our tenants and facilitating meeting other, non-shelter needs that they have, including food security, transportation access and health. The indicators and measures we have chosen for this dimension are primarily measured at the household level and are drawn from the City of Vancouver's social sustainability framework (2005). These measures are outlined in Table 19.3. 
TABLE 19.3 Indicators and Measures for Dimension 2: Non-Housing Needs

\begin{tabular}{|c|c|c|c|}
\hline Indicator & Measure & Data Source & Target \\
\hline $\begin{array}{l}\text { Capacity to support } \\
\text { self/family }\end{array}$ & $\begin{array}{l}\text { Change in ability to support } \\
\text { self/family }\end{array}$ & Well-being survey & Increase \\
\hline \multirow[t]{4}{*}{ Food security } & Access to good food (quality) & Well-being survey & Increase \\
\hline & Healthy eating habits & Well-being survey & Increase \\
\hline & Frequency of food bank use & Well-being survey & Decrease \\
\hline & Ability to afford food & Well-being survey & Increase \\
\hline \multirow[t]{3}{*}{ Transportation } & Proximity Measures & CMHC/Statistics Canada & Increase \\
\hline & $\begin{array}{l}\text { Percentage of tenants who are satisfied } \\
\text { with access to transit }\end{array}$ & Well-being survey & Increase \\
\hline & $\begin{array}{l}\text { Number of tenants accessing Ride } \\
\text { Transit Program }\end{array}$ & Partner agencies & Increase \\
\hline \multirow[t]{4}{*}{ Health } & Mental health - feelings of stress & Well-being survey & Decrease \\
\hline & $\begin{array}{l}\text { Physical health - satisfaction with } \\
\text { access to medical care }\end{array}$ & Well-being survey & Increase \\
\hline & $\begin{array}{l}\text { Physical health - satisfaction with } \\
\text { access to dental care }\end{array}$ & Well-being survey & Increase \\
\hline & $\begin{array}{l}\text { Satisfaction with overall personal } \\
\text { health }\end{array}$ & Well-being survey & Increase \\
\hline \multirow[t]{3}{*}{ Financial stability } & $\begin{array}{l}\text { Percentage of tenants with stable } \\
\text { (non-temporary) income sources }\end{array}$ & Administrative data & Increase \\
\hline & $\begin{array}{l}\text { Percentage of tenants who indicate } \\
\text { that income meets their needs }\end{array}$ & Well-being survey & Increase \\
\hline & $\begin{array}{l}\text { Percentage of tenants who struggle to } \\
\text { pay bills }\end{array}$ & Well-being survey & Decrease \\
\hline \multirow[t]{3}{*}{ Safety } & $\begin{array}{l}\text { Percentage of tenants who feel safe in } \\
\text { community }\end{array}$ & Well-being survey & Increase \\
\hline & Neighbourhood crime rates & Edmonton police service & Decrease \\
\hline & $\begin{array}{l}\text { Percentage of tenants who feel safe } \\
\text { with family }\end{array}$ & Well-being survey & Increase \\
\hline
\end{tabular}

Source: Capital Region Housing.

\section{Dimension 3A: Community Integration and Social Inclusion}

It is crucial to recognize that housing - the places we live in and make our home - is the primary built form impacting the social sustainability of the city and largely mediates our experiences of social sustainability at the individual level. Housing occupies a unique role, spatially situating its occupants within a neighbourhood and city, but also socially impacting its occupants (Dunn et al., 2006).

Further, urban social sustainability research typically emphasizes the role of the urban built environment on social sustainability and, more specifically, explores the impact of housing types and characteristics on social sustainability, such as higher density, mixed use and location to amenities and green space (Bramley et al., 2006; 2009; Ancell \& Thompson-Fawcett, 2008; Dempsey et al., 2011). By focusing on the built environment, the neighbourhood and the city, and their relationship with social sustainability, the concept takes on a specific spatial dimension (Polèse \& Stren, 2000; Dempsey et al., 2011).

As a housing provider, then, we need to consider this socio-spatial role of housing and work to ensure our housing is integrated into the community and reduces socio-spatial exclusion, as identified by Polèse and Stren (2000), and has good access to supportive urban factors, as 
TABLE 19.4 Indicators and Measures for Dimension 3A: Community Integration and Social Inclusion

\begin{tabular}{llll}
\hline Indicator & Measure & Data Source & Target \\
\hline $\begin{array}{l}\text { Community } \\
\text { integration }\end{array}$ & $\begin{array}{l}\text { Percentage of all tenants involved in tenant } \\
\text { advisory activities } \\
\text { Volunteer engagement in community } \\
\text { organizations }\end{array}$ & Administrative data & Increase \\
& $\begin{array}{l}\text { Political engagement (advocacy efforts, volunteer } \\
\text { for political candidates or parties, voting) }\end{array}$ & Well-being survey & Increase \\
& Engagement in a religious or spiritual community survey & Increase \\
& $\begin{array}{l}\text { Ability to influence community } \\
\text { Access to social services }\end{array}$ & $\begin{array}{l}\text { Well-being survey } \\
\text { Social inclusion }\end{array}$ & Increase \\
& Supportive networks & Well-being survey & Increase \\
& Feeling of belonging & Well-being survey & Increase \\
& Feeling of fair treatment (inclusion) & Well-being survey & Increase \\
& Social inclusion index & Well-being survey & Increase \\
& & CMHC/Statistics & Increase \\
& & Canada & \\
\hline
\end{tabular}

Source: Capital Region Housing.

highlighted by Dempsey and colleagues (2011). This set of indicators and measures reflect the socio-spatial role of housing, with measures for community integration focusing on capacity, participation and engagement (City of Vancouver, 2005), and measures for social inclusion focusing on geography and the built environment (Ancell \& Thompson-Fawcett, 2008; Bacon, Cochrane \& Woodcroft, 2012). These measures are outlined in Table 19.4.

\section{Dimension 3B: Capacity Building and Resiliency}

Equally though, as a housing provider, we must consider the people who live in our housing and their higher-order needs. Reflecting this importance and recognizing that the people that live in our housing are reciprocally impacted by the socio-spatial aspect of housing (Dimension $3 \mathrm{~A}$ ), these two dimensions are placed at an equal level in the framework. As identified in the City of Vancouver's (2005) social sustainability definition, supporting higher-order needs in the context of social sustainability is particularly centred around working to build individual capacity and resiliency.

Reflecting on resiliency in more detail, individual resilience should not be seen as an individual trait, although it remains coupled with individual capacities, relationships and availability of community resources (Liebenberg \& Moore, 2018). As with community resilience, defining individual resilience involves disruption, or adversity followed by adaptation and growth (Liebenberg \& Moore, 2018). However, it can be difficult to identify causal influences (Rutter, 2012) as well as measuring adaptation and growth (Liebenberg \& Moore, 2018). What is clear is that individual resilience is influenced by the social and physical environment as well as more individual factors/capabilities (Liebenberg \& Moore, 2018; Rutter, 2012). As it relates to what level of individual capabilities people must have, Doorn, Gardoni and Murphy (2018) suggest that from a social justice perspective, determining an acceptable level of individual factors requires that all people are able to be placed above the threshold level and that an average level is insufficient.

In recent decades, models for understanding resilience in children and adults have moved away from a biomedical view, which located the source of illness in an individual, towards an ecological systems approach that views the individual as situated in their family and community 
TABLE 19.5 Indicators and Measures for Dimension 3B: Capacity Building and Resiliency

\begin{tabular}{|c|c|c|c|}
\hline Indicator & Measure & Data Source & Target \\
\hline \multirow[t]{5}{*}{$\begin{array}{l}\text { Education and capacity } \\
\text { building }\end{array}$} & $\begin{array}{l}\text { Satisfaction with access to } \\
\text { personal development } \\
\text { opportunities }\end{array}$ & Well-being survey & Increase \\
\hline & $\begin{array}{l}\text { Satisfaction with access to } \\
\text { libraries }\end{array}$ & Well-being survey & Increase \\
\hline & $\begin{array}{l}\text { Satisfaction with access to } \\
\text { recreation }\end{array}$ & Well-being survey & Increase \\
\hline & $\begin{array}{l}\text { Number of tenants accessing } \\
\text { Leisure Access Pass }\end{array}$ & $\begin{array}{l}\text { Administrative data/partner } \\
\text { agencies }\end{array}$ & Increase \\
\hline & $\begin{array}{l}\text { Number of partnerships or } \\
\text { MOUs between CRH } \\
\text { and community partner } \\
\text { agencies }\end{array}$ & $\begin{array}{l}\text { Administrative data/partner } \\
\text { agencies }\end{array}$ & Increase \\
\hline \multirow[t]{3}{*}{ Access to employment } & $\begin{array}{l}\text { Percentage of tenants who } \\
\text { change status from student } \\
\text { to employed }\end{array}$ & Administrative data & Increase \\
\hline & $\begin{array}{l}\text { Percentage of tenants with } \\
\text { full-time employment }\end{array}$ & Administrative data & Increase \\
\hline & $\begin{array}{l}\text { Percentage of tenants } \\
\text { in mixed-income } \\
\text { developments who increase } \\
\text { their income over the } \\
\text { Household income limits } \\
\text { due to employment income }\end{array}$ & Administrative data & Increase \\
\hline Resiliency & $\begin{array}{l}\text { Statistics Canada resiliency } \\
\text { measures }\end{array}$ & Well-being survey & Increase \\
\hline
\end{tabular}

Source: Capital Region Housing.

relational networks (O’Dougherty Wright, Masten, \& Narayan, 2013). This perspective on resilience recognizes the role that environmental and social factors can have in developing resiliency in individuals. Many of the identified "protective factors" that provide some form of shielding from the negative effects of risk or adversity are also factors that reoccur in social sustainability frameworks, such as levels of community violence, access to affordable housing and good public health care (see City of Vancouver, 2005; Colantonio et al., 2009; Dempsey et al., 2011).

Resiliency, like social sustainability, has many different measures. We focus on the measures for resiliency as developed by Statistics Canada (2019) for their Canadians at Work and Home survey, which allows us to compare our results to national data and ensures that these measures are valid and reliable. We also include measures for education and capacity building and access to employment, again drawing from the City of Vancouver's (2005) framework. These measures are outlined in Table 19.5.

\section{Key Measures of Social Sustainability}

Because of the multidimensional and multi-scalar nature of social sustainability and recognizing that these measures are a mix of quantitative and qualitative data, these measures cannot be summed or aggregated into a single total measure of social sustainability. Rather, we have 
TABLE 19.6 Key Measures in Capital Region Housing Social Sustainability Framework

\begin{tabular}{|c|c|c|}
\hline Dimension & Indicator & Key Measure \\
\hline 1: Housing standards & Affordable & Percentage of priority (wait) list allocated housing \\
\hline 2: Non-housing needs & $\begin{array}{l}\text { Capacity to support } \\
\text { self/family }\end{array}$ & Change in ability to support self/family \\
\hline $\begin{array}{l}\text { 3A: Community integration } \\
\text { and social inclusion }\end{array}$ & Social inclusion & Feeling of belonging \\
\hline $\begin{array}{l}\text { 3B: Capacity building and } \\
\text { resiliency }\end{array}$ & $\begin{array}{l}\text { Education and } \\
\text { capacity building }\end{array}$ & $\begin{array}{l}\text { Number of partnerships or MOUs between CRH } \\
\text { and community partner agencies }\end{array}$ \\
\hline
\end{tabular}

Source: Capital Region Housing.

chosen four key measures for each dimension of social sustainability. These key measures are not intended to reflect the full breadth and depth of each set of measures for each dimension. However, we argue that they do capture the goal of each dimension and serve as a snapshot of the social sustainability of social and affordable housing and the people who call our housing home. These key measures are summarized in Table 19.6.

In order to visualize our progress along these indicators, we suggest using a red-ambergreen (RAG) or traffic light rating system, similar to the Berkley Group (Bacon, Cochrane \& Woodcraft, 2012). This system requires first setting a baseline for each measure, and then setting target increases or decreases in this measure. In this visualization, green indicates a positive result where we meet or exceed the target; yellow is near the target or static; and red is below the target. Through this visualization system, we will be able to visually assess how our actions have contributed to social sustainability and quickly see indicators where more action is needed.

\section{Conclusions}

In this chapter, we have developed a framework for measuring social sustainability that is specific to the context of social and affordable housing and to our role as an affordable housing provider. It clarifies housing's role within the social sustainability paradigm, recognizing that because of housing's role in meeting basic and higher-order needs, and its socio-spatial role in the city and people's lives, housing provides a key entry point to improving and mediating people's experiences of social sustainability. This provides social and affordable housing providers with a specific point for operationalizing social sustainability within their work, as Capital Region Housing has done by focusing on both our housing and our tenants. This framework is also scalable and can be measured at the level of individual buildings, neighbourhoods or across the Capital Region Housing portfolio of over 5,000 homes. This framework is also specific to the Alberta context for social and affordable housing, and includes some measures specific to the Alberta regulatory framework, such as the percentages of tenants in mixed-income developments who increase their income over the income thresholds.

Our framework includes "inter and intragenerational equity" as a key feature, and grounds social sustainability in the project of improving quality of life, not simply measuring it. Therefore, while it is important to view any measure of social sustainability as a snapshot of the community's strength and quality of life at a single point in time (Bacon, Cochrane, \& Woodcraft, 2012), it is between these snapshots that the work of social sustainability occurs, with indicators and measuring guiding future actions to support social sustainability. We plan to measure social sustainability biennially, so that we can compare our progress across time. The framework, based on Maslow's hierarchy of needs, also prioritizes action, focusing on meeting basic needs first. 
Our framework also specifically recognizes the important role our partners play in supporting social sustainability. Some of the measures included here go beyond those generally indicated as the responsibilities of housing providers in the literature (Dixon \& Woodcraft, 2013), such as supporting tenants in meeting basic needs such as food security. Capital Region Housing, as an affordable housing provider with a commitment to a holistic understanding of social sustainability, recognizes that meeting basic needs may be a persistent problem for tenants who have low income and struggle with poverty. The organization has chosen to expand its framework to include indicators that can be improved through partnerships with community and non-profit organizations, municipal services and various levels of government.

Further, it is essential that indicators of social sustainability be viewed holistically in relation to one another, as social sustainability is multidimensional. Dillard and colleagues (2009) caution that there are interactive relationships between social and environmental sustainability, and the two do not always align in the same direction. The conceptualization of social sustainability developed by Capital Region Housing considers it as distinct from, but connected to, environmental and financial sustainability. None of the social sustainability frameworks reviewed in this chapter tried to capture all three forms of sustainability in one measurement system, and indeed this type of evaluation would likely be too unwieldy to be useful. However, future work in this area should focus on developing methods for putting the measurement frameworks for each form of sustainability in conversation with one another to gain a picture of the relationship between the three interrelated forms of sustainability.

Overall, this is the first iteration of the development of a social sustainability measurement framework in the context of social and affordable housing in Alberta. We are in the process of testing these measures and setting goals, and we anticipate that this framework will continue to evolve in future iterations, as the field of social sustainability continues to expand and there is increased research in the social and affordable housing sector.

\section{Acknowledgement}

We gratefully acknowledge the work done by Kenzie Gordon through the University of Alberta's Sustainability Scholars programme that assisted with the development of this measurement framework.

\section{Note}

1 We differentiate social and affordable housing whereby social housing uses a rent geared-to-income approach to setting rent, and affordable housing have rents that are approximately $10-20 \%$ lower than market rent housing.

\section{References}

Ancell, S.; and Thompson-Fawcett, M. (2008). The social sustainability of medium density housing: A conceptual model and Christchurch case study. Housing Studies, 23(3): 423-442.

Bacon, N.; Cochrane, D.; and Woodcraft, D. (2012). Creating strong communities: How to measure the social sustainability of new housing developments. Cobham: Berkeley Group.

Boström, M. (2012). A missing pillar? Challenges in theorizing and practicing social sustainability: Introduction to the special issue. Sustainability: Science, Practice and Policy, 8(1): 3-14.

Bramley, G.; Dempsey, N.; Power, S.; and Brown, C. (2006). What is "social sustainability", and how do our existing urban forms perform in nurturing it. Sustainable Communities and Green Futures' Planning Research Conference. Bartlett School of Planning, University College London, London. 
Bramley, G.; Dempsey, N.; Power, S.; Brown, C.; and Watkins, D. (2009). Social sustainability and urban form: Evidence from five British cities. Environment and Planning A, 41(9): 2125-2142.

Brundtland, G. (1987). Our common future: Report of the 1987 World Commission on Environment and Development. New York: United Nations.

Capital Region Housing. (2018). Tenant Wellbeing Community Report 2018. www.crhc.ca/reports-andpublications, accessed December 22, 2020.

Carlson, M. J.; and Everett, M. (2013). "Social sustainability and the social determinants of health." In Dujon, V.; Dillard, J.; and Brennan, E. M. (eds). Social sustainability: A multilevel approach to social inclusion (pp. 103-125). New York: Routledge.

Carter, T.; and Polevychok, C. (2004). Housing is good social policy. Ottawa: Canadian Policy Research Networks.

Chiu, R. L. (2003). "Social sustainability, sustainable development and housing development: The experience of Hong Kong." In Forrest, R.; and Lee, J. (eds) Housing and social change: East-west perspectives (pp. 221-239). London: Routledge.

CIH UK. (2015). New Approaches to delivering social value. Coventry: Chartered Institute of Housing.

City of Edmonton. (2010). The way we live: Edmonton's people plan. Edmonton: City of Edmonton.

City of Edmonton. (2012). The way we live implementation plan. Edmonton: City of Edmonton.

City of Vancouver. (2005). Definition of social sustainability. Policy report, social development. Vancouver: City of Vancouver.

City of Vancouver. (2006). City of Vancouver social development plan update. Vancouver: City of Vancouver.

CMHC-SCHL. (2004). Housing and population health - research framework. Research Highlight, Socioeconomic Series 04-016. Ottawa: CMHC-SCHL.

CMHC-SCHL. (2020). NHS housing needs data. www.cmhc-schl.gc.ca/en/nhs/housing-needs-data, accessed December 22, 2020.

Colantonio, A. (2009). "Social sustainability: A review and critique of traditional versus emerging themes and assessment methods." In Horner, M.; Price, A.; Bebbington, J.; and Emmanuel, R. (eds). SUEMOT. Conference 2009: Second international conference on whole life urban sustainability and its assessment: Conference proceedings (pp. 865-885). Loughborough: Loughborough University.

Colantonio, A.; and Dixon, T. (eds). (2011). Urban regeneration and social sustainability: Best practice from European cities. West Sussex: Wiley-Blackwell.

Colantonio, A.; Dixon, T.; Ganser, R.; Carpenter, J.; and Ngombe, A. (2009). Measuring socially sustainable urban regeneration in Europe. Oxford: Oxford Institute for Sustainable Development.

Committee on Economic, Social and Cultural Rights. (1991). General comment no. 4: The right to adequate housing. New York: United Nations.

Davidson, M. (2010). Social sustainability and the city. Geography Compass, 4(7): 872-880.

Dempsey, N.; Bramley, G.; Power, S.; and Brown, C. (2011). The social dimension of sustainable development: Defining urban social sustainability. Sustainable Development, 19: 289-300.

de Vos, E.; and Severson, M. (2018). Conceptualizing social sustainability in the canadian social and affordable housing sector. Paper presented at the XIX ISA World Congress of Sociology. Toronto, July.

Dillard, J.; Dujon, V.; and King, M. C. (eds) (2009). "Introduction." In Understanding the social dimension of sustainability (pp. 1-12). New York: Routledge.

Dixon, T.; and Woodcraft, S. (2013). Creating strong communities: Measuring social sustainability in new housing development. Town and Country Planning: 473-480.

Doorn, N.; Gardoni, P.; and Murphy, C. (2019). A multidisciplinary definition and evaluation of resilience: The role of social justice in defining resilience. Sustainable and Resilient Infrastructure, 4(3): 112123.

Dujon, V.; Dillard, J.; and Brennan, E. M. (eds). (2013). Social sustainability: A multilevel approach to social inclusion. New York: Routledge.

Dunn, J. R.; Hayes, M. V.; Hulchanski, J. D.; Hwang, S. W.; and Potvin, L. (2006). Housing as a socioeconomic determinant of health: Findings of a national needs, gaps and opportunities assessment. Canadian Journal of Public Health/Revue Canadienne de Santé Publique, 97(3): S11-S15.

Government of Alberta. (2017). Provincial affordable housing strategy. https://open.alberta.ca/publications/9781460134160, accessed December 22, 2020. 
Government of Canada. (2017). National housing strategy: A place to call home. https://assets.cmhc-schl.

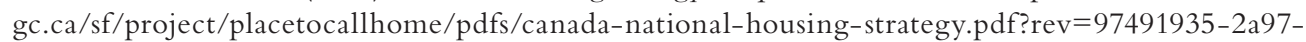
405f-bd38-decf72266ee9, accessed December 22, 2020.

Kirkpatrick, S. I.; and Tarasuk, V. (2007). Adequacy of food spending is related to housing expenditures among lower-income Canadian households. Public Health Nutrition, 10(12): 1464-1473.

Liebenberg, L.; and Moore, J. C. (2018). A social ecological measure of resilience for adults: The RRCARM. Social Indicators Research, 136(1): 1-19.

Littig, B.; and Griessler, E. (2005). Social sustainability: A catchword between political pragmatism and social theory. International Journal of Sustainable Development, 8(1-2): 65-79.

Magis, K. (2010). Community resilience: An indicator of social sustainability. Society E Natural Resources, 23(5): 401-416.

Magis, K.; and Shinn, C. (2009). "Emergent principles of social sustainability.” In Dillard, J.; Dujon, V.; and King, M.C. (eds). Understanding the social dimension of sustainability (pp. 15-44). New York: Routledge.

Manzi, T.; Lucas, K.; Lloyd Jones, T.; and Allen, J. (2010). "Understanding social sustainability: Key concepts and developments in theory and practice.” In Manzi, T.; Lucas, K.; Lloyd Jones, T.; and Allen, J. (eds). Social sustainability in urban areas: Communities, connectivity, and the urban fabric (pp. 1-28). London: Earthscan.

McKenzie, S. (2004). Social sustainability: Towards some definitions. Magill: Hawke Research Institute, University of South Australia.

Murphy, K. (2012). The social pillar of sustainable development: A literature review and framework for policy analysis. Sustainability: Science, Practice and Policy, 8(1): 15-29.

O’Dougherty Wright, M.; Masten, A. S.; and Narayan, A. J. (2013). "Resilience processes in development: Four waves of research on positive adaptation in the context of adversity." In Goldstein, S.; and Brooks, R. (eds). Handbook of resilience in children (pp. 15-37). New York: Springer.

Polèse, M. (2000). "Learning from each other: Policy choices and the social sustainability of cities." In Polèse, M.; \& Stren, R. (eds) The social sustainability of cities: Diversity and the management of change (pp. 308-334). Toronto: University of Toronto Press.

Polèse, M.; and Stren, R. (eds). (2000). The social sustainability of cities: Diversity and the management of change. Toronto: University of Toronto Press.

Pullen, S.; Arman, M.; Zillante, G.; Zuo, J.; Chileshe, N.; and Wilson, L. (2010). Developing an assessment framework for affordable and sustainable housing. The Australasian Journal of Construction Economics and Building, 10(1/2): 60-76.

Richardson, J. (2010). Housing and the customer: Understanding needs and delivering service. Coventry: Chartered Institute of Housing.

Rutter, M. (2012) Resilience as a dynamic concept. Development and Pyschopathy, 24: 335-344.

Shirazi, M. R.; and Keivani, R. (2019). The triad of social sustainability: Defining and measuring social sustainability of urban neighbourhoods. Urban Research \& Practice, 12(4): 448-471.

Statistics Canada. (2017). 2016 census of population: Housing. Release and Concepts Overview. www12.statcan. gc.ca/census-recensement/2016/ref/98-501/98-501-x2016007-eng.cfm, accessed December 22, 2020.

Statistics Canada. (2019). General social survey: An overview, 2019. Ottawa: Statistics Canada.

Statistics Canada. (2020). Proximity measures data viewer. www150.statcan.gc.ca/n1/pub/71-607-x/71607-x2020011-eng.htm, accessed December 22, 2020.

Stren, R.; and Polèse, M. (2000). "Understanding the new sociocultural dynamics of cities: Comparative urban policy in a global context.” In Polèse, M.; \& Stren, R. (eds) The social sustainability of cities: Diversity and the management of change (pp. 3-38). Toronto: University of Toronto Press.

Vallance, S.; Perkins, H. C.; and Dixon, J. E. (2011). What is social sustainability? A clarification of concepts. Geoforum, 42(3): 342-348.

Vanclay, F. (2003). International principles for social impact assessment. Impact Assessment and Project Appraisal, 21(1): 5-12.

Woodcraft, S. (2012). Social sustainability and new communities: Moving from concept to practice in the UK. Procedia-Social and Behavioral Sciences, 68: 29-42. 